\title{
The Physical Space and the Development of Creativity in Peruvian Early Childhood Education: A Case Study in Arequipa
}

\author{
Karol Andrea Puma-Yagua \\ Universidad Nacional de San Agustín \\ Arequipa, Perú \\ Teresa Ramos-Quispe \\ Universidad Continental \\ Arequipa, Perú \\ Sonia Esther Castro-Cuba-Sayco \\ Universidad Católica de Santa María \\ Arequipa, Perú \\ Alicia García-Holgado \\ GRIAL Research Group, University of Salamanca \\ Salamanca, Spain \\ Antonio Silva Sprock \\ Universidad Central de Venezuela \\ Caracas, Venezuela \\ Klinge Orlando Villalba-Condori \\ Universidad Continental \\ Arequipa, Perú
}

\begin{abstract}
Creativity is a significant flaw that is observed in the Peruvian educational system, and that has its origins in initial education. The purpose of this research is to know the influence of the use of physical space in the development of creativity among pupils of 5-years-old classes of the initial level in Arequipa. In particular, the study was carried out in eight public schools of the Local Educational Management Units of South Arequipa and Caylloma, with 151 students. Two instruments were used, one to evaluate the physical space and an adaptation of the Torrance Tests of Creative Thinking. It was found that there is a relationship between the use of physical space and the development of creativity in children of the 5-years-old at the public educational institutions of the Caylloma and South Arequipa.
\end{abstract}

Keywords: Physical space; Creativity; Pre-school 


\section{Introduction}

In recent years, pedagogues, architects and teachers have shown great interest in the analysis and study of the physical school space in different regions of the world. In the Peruvian context, however, little research has been carried out on this subject. In order to develop creativity in schools, it is necessary to innovate educational methods, motivate students, redesign the physical space, rethink academic hours, take advantage of technology, and so on. The physical space must be considered an element of the teaching activity, and even more at the initial level; therefore, it is necessary to structure and organize it adequately. This is corroborated by the research of Alonso-Sanz (2016), who concluded that children are capable of critically examining their daily educational spaces and expressing their opinions supported by visual forms of communication.

For María Montessori, the child takes play very seriously, as work; it is known that the child learns through play, be it free play or guided play; and for this, correctly implemented spaces are needed, without excess or lack of materials. The technological advances have fostered the development of different areas of society. However, the infrastructure of the schools has not changed, classrooms remain rectangular, and students are sitting in front of a blackboard (digital or traditional) (Britton, 1992).

There are previous studies that show the importance of the topic addressed here. These include research by Vintimilla and Muñoz (2018), who conclude that of the ten centres evaluated in the Canton of Cuenca (Ecuador), $90 \%$ of them do not meet all the quality standards; and only one children's centre located in the urban area meets all the standards evaluated, which represents $10 \%$. Also noteworthy is the study carried out on children in a private-concerted Early Education school in the province of Granada (Spain) (López-Megías, 2018). For these authors, the use of qualitative analysis methodologies as an evaluation alternative allows access to an analysis of creativity in early childhood, an area in which there are not too many standardized instruments or those with sufficient validity and reliability. Pagliero and Piderit (2017) conclude in their study that the best orientation for kindergarten classrooms is the Northeast, given the hours of use of the children and the inclination of the sun in the city of Puerto Montt, which corresponds to what is recommended by UNESCO. Finally, Medina, Velázquez, Alhuay and Aguirre (2017) shows as practical results the development of a didactic strategy that contributed to improving the creative capacity of children in early education in Puno (Peru).

At present, we are living with problems that are affecting humanity, such as the economic crisis, scarcity of energy resources, global warming, and so on. The 21st century will be full of changes that will be inevitable, and all human beings must commit themselves to find solutions to these problems; this is where creativity emerges to find solutions and ideas to stop the many problems with which we live. For this reason, it is necessary to know the importance of creativity in the personal and social development of the human being, from an early age. 
Creativity acquires, then, double importance and meaning. On the one hand, as a cultural value that allows generating effective solutions to contemporary problems. On the other hand, as a fundamental need of the human being, whose satisfaction allows reaching a better quality of life. According to (Klimenko, 2008), the development of creativity is significant because it will make it possible to provide solutions to the current problems of society.

Creativity is a significant flaw that is observed in the Peruvian educational system, and that has its origins in initial education. In this context, this study aims to analyse the influence of the physical space in the development of creativity among pupils of five years old in two different provinces in the Department of Arequipa (Peru), Arequipa and Caylloma. In particular, the study was carried out in public schools of the Local Educational Management Units of South Arequipa and Caylloma. The proposed hypothesis is that physical space is one of the determining factors for the development of creativity in children in the 5-year-old classroom of the public educational institutions in South Arequipa and Caylloma.

\section{Physical Space}

For Iglesias (2008), the physical space refers to the classroom, where the furniture, materials, and decoration are for the work with children. From this concept, it can be deduced that the physical space is constituted by the scenarios where the children's learning takes place.

Along the same lines, García-Chato (2014) specifies that the physical space is the place where the child lives, learns and relates to objects and others. Thus, this space becomes "a network of places and objects that human beings can experience directly through the experiences they may have, through opportunities to learn, to know, and to relate". García-Chato refers to space as an essential entity for the development of the child, since in it he will experience new sensations and will relate to the objects that surround him, in such a way that he will be able to recognize them as part of his space. The Peruvian Ministry of Education concludes that adequate school infrastructure has a positive effect on student performance (How is the school infrastructure related to student learning?, 2017).

Educational spaces must be renovated according to the methodology used. There is no single successful design since it will depend on the context, pedagogical objectives, methodology, and policy of educational institutions. Several schools in Europe and Asia were remodelled with one direction in mind: versatility, polyvalence, and transparency.

According to the Peruvian early education curriculum (Quality educational environment in initial education, 2016), the organization of educational spaces, the fair and pertinent use of educational materials and resources, as well as the teaching role provide environments and interactions that allow for a favourable climate for learning. For this reason, it is essential to have a relevant space; the classroom must have an infrastructure that provides physical security, adequate 
furniture, and materials according to the age of the child so that the learning processes take place in the best way. In the organization of the classroom for school activities, the furniture and materials should be arranged so that they influence the child's learning activities.

According to the learning routes of the initial level (Learning routes, 2015), the Peruvian Ministry of Education has promoted the use of diverse play areas in the early education classrooms; in these, children are encouraged to express themselves through diverse languages. It can be understood that the organization of the play areas is an important part of the initial level where children interact with other children and with classroom materials through free play. The opinion of the children must be taken into account in order to locate, name, and arrange the play areas in the space. Play areas are spaces inside or outside the classroom where children play freely, going to an area voluntarily, interacting with each other, developing their creativity and intelligence, and building on their learning. To this end, all the posters in the classroom must be made by the children using graphic-plastic techniques, with the guidance of the classroom teacher. Classroom posters should preferably be made in the first weeks of the school year (How is the school infrastructure related to student learning?, 2017).

Cayuela (2018) affirms in an interview that the infrastructure of schools is the same as those of 30 years ago. However, some private schools know what to do to attract 'clients' and seek new educational methodologies and innovative architecture. On the other hand, the architecture of public schools has not been modified in several decades, not because of a budget problem, but because of a lack of research and commitment.

Regarding space in educational centres, Polanco explains that "it is relevant to consider space, the distribution of furniture, since these elements contribute to the interpersonal relationships that take place within the classroom, favour the construction of knowledge and collaborate with the success of learning situations" (Polanco, 2004).

On the physical environment of the school, (Ruiz \& Rebolledo, 2015) points out that the organization of the school environment is a broad concept that will influence the daily life of the classroom, so it is necessary to provide rich and stimulating scenarios full of possibilities and challenges that allow children to explore and experience from it as a learning centre.

\section{Development of creativity}

A modern approach to the concept of creativity is offered by Cernades Ramírez, who considers it as "an inherent characteristic of the human being, susceptible to being stimulated by the social and family environment of the child. In every human being, there is the impulse to experiment, to investigate, to relate, in short, to create" (Cernades, 2008). She refers to creativity as something inseparable from the human being and which must be stimulated. It can be understood that all human beings are creative, but not all develop their 
creativity in the same way as others because they are not stimulated at the same level.

Creativity can also be understood as a vital impulse, as a way of stimulating and leading the development of the human being. According to Astorga (2016) "Creativity must be understood as one of the motors that move the human being. It can be recognized as the vital energy to relate to and face the challenges that the environment indicates day by day."

Guilford (1950) argues that while there is no direct relationship between intelligence and creativity (or if there is one, it is to a low degree), this is because intelligence tests do not measure all the aptitudes of intelligence, including those directly involved in creativity. Guilford does not assume in his theory that intelligence and creativity are different, but that "creativity is within intelligence (divergent thinking)."

Torrance (1962), in his threshold hypothesis, explains the relations between intelligence and creativity, postulating that when Intelligence Quotient (IQ) is below a certain limit, creativity is also limited, while when IQ is above this limit (IQ: 115-120), creativity becomes an almost independent dimension of IQ. In other words, a certain intellectual level is necessary, but not sufficient, condition for the development of creativity.

There are authors, such as Gardner (1983), who have ceased to see intelligence as something unitary and compact, diversifying intelligences. According to his theoretical approaches, creativity and intelligence are the same; in fact, his definitions of a creative person and intelligent person are identical.

Children show creativity in play; they explore experiment, investigate, discover, and succeed in overcoming obstacles. It is necessary to become a creative society by cultivating children's creativity to empower them. According to CernadesRamirez (2008), if from the first moment we manage to maintain this freedom, this naturalness, giving them self-confidence, we can ensure that this development does not diminish. Creativity can best be developed in teams since people will have different points of view on the problem posed, and together they will be able to give solutions in a complete and detailed way. The members of the group must have a close and effective interaction; they must be respected, understood, and participated constantly. Creativity is to combine points with a value of originality for society. The more books that are read, the more creative results can be achieved. There is a straightforward correlation between early childhood reading and creative outcomes. According to Hinostroza (2007), all artistic activities help the child's creative development and imagination.

\section{Methodology}

Below we show the methodology used, where we detail the participants involved in the study, including the institutions and the number of people in each institution. In the same way we detail the instruments used, the design of the study and the collection of data and results of the work. 


\subsection{Participants}

The population consisted in childrens of five-years-old of classrooms of public educational institutions at the initial level of the Local Educational Management Units (UGEL) of Caylloma and South Arequipa. The sample is non-probabilistic and intentional since the inclusion criteria considered similar aspects in terms of the number of students and proximity to educational institutions, to facilitate the study, reasons valid in this investigation.

The initial level schools selected in the UGEL Caylloma were by proximity, 4 schools were selected in the town of Chivay, 2 single-teacher schools and 2 multi-teacher schools. The schools were I.E.I. Los Angelitos, the Divino Niño Jesús, the I.E.I. Los Patitos II, and the I.E.I. Jardines del Colca, where we studied 86 children of seven classrooms of these schools.

At UGEL south in the city of Arequipa, the same factor was taken into account and the schools were taken in the Mariano Melgar district, specifically the G.U.E. Mariano Melgar, I.E. Manuel Veramendi and Hidalgo, I.E. Teniente Diego Ferré and the I.E.I. Alto Mariano Bustamante. In these schools we studied 65 students from 5 classrooms. In total 141 childrens.

\subsection{Instruments}

Two instruments were used in the study. The first instrument is an adaptation of the "guideline for the management of space and materials in the classroom" (http://bit.ly/2MRUrUb) (Observation guideline for classroom space and materials management, 2017) defined by the Peruvian Ministry of Education as part of the evaluation model of Teaching Performance Beginning Level. The instrument evaluates, through inspection of the classroom as a physical space, the extent to which the teacher ensures compliance with criteria of safety, cleanliness, accessibility, and organization, to promote the development and learning of children in their care. The instrument was focused on the organization part and 6 items were added to evaluate the play areas and the materials used in each area. This instrument also evaluates the posters that are used, such as attendance, the calendar, etc. which has to be made by the children themselves. The second instrument is an adaptation of the Torrance Tests of Creative Thinking (TTCT) (Torrance, 1972; Kim, 2006).

The TTCT is made up of 3 games, the 1st game consists of the children making a drawing using a green leaf in the shape of an egg; the 2nd game consists of completing drawings and the 3rd game in making as many drawings as possible using 2 parallel lines as a base. All games were adapted in order to remove the part in which children have to write a title per each draw, due to 5-years-old children do not write or read. This part was replaced by a question of the person who applied the instrument. She asked the children what they were drawing. The response table was adapted to the Peruvian reality through a blank test conducted in other institutions of Local Educational Management Units of Caylloma and South Arequipa. 


\subsection{Study design and data collection}

It is descriptive research. It focuses on the use of physical space in the educational centres of the Local Educational Management Units of Caylloma and South Arequipa. The investigation is not experimental because a deliberate manipulation of variables was not carried out; only the phenomena were observed in their natural environment and later analysed.

Two data collection techniques were used. First, the researchers observed the centres objectively without getting involved in the environment. Second, the instrument was applied.

The visits to the educational institutions were made in October 2018. The classrooms were observed before the children's admission time, with the accompaniment of the directors and / or teachers of the classroom. The TTCT was applied in October also, each game is 10 minutes, and then each child was asked personally about the drawings made.

The data collected was imported in SPSS Statistics v.24 to carry out the statistical tests.

\section{Results}

A code was assigned to identify schools from Caylloma (CY) and those from South Arequipa (SA). First, a descriptive analysis between schools peers was conducted.

\begin{tabular}{|c|c|c|c|c|}
\hline Group & Location & Schools & $\begin{array}{c}\text { Physical } \\
\text { space }\end{array}$ & Creativity \\
\hline 1 & Caylloma & I.E.I. Los Patitos II & 2.56 & $66.7 \%$ \\
\hline 1 & $\begin{array}{c}\text { South } \\
\text { Arequipa }\end{array}$ & $\begin{array}{c}\text { I.E.I. Alto Mariano } \\
\text { Bustamante }\end{array}$ & 2.37 & $83.3 \%$ \\
\hline 2 & Caylloma & I.E.I. Jardines del Colca & 2.75 & $57.1 \%$ \\
\hline 2 & $\begin{array}{c}\text { South } \\
\text { Arequipa }\end{array}$ & I.E. Teniente Diego Ferré & 2.37 & $66.7 \%$ \\
\hline 3 & Caylloma & I.E.I. Divino Niño Jesús & 2.75 & $64.0 \%$ \\
\hline 3 & $\begin{array}{c}\text { South } \\
\text { Arequipa }\end{array}$ & G.U.E. Mariano Melgar & 2.68 & $36.7 \%$ \\
\hline 4 & Caylloma & I.E.I. Los Angelitos & 2.75 & $76.9 \%$ \\
\hline 4 & $\begin{array}{c}\text { South } \\
\text { Arequipa }\end{array}$ & $\begin{array}{c}\text { I.E. Manuel Veramendi e } \\
\text { Hidalgo }\end{array}$ & 2.25 & $56.3 \%$ \\
\hline
\end{tabular}

The hypothesis was tested by Analysis of Variance (ANOVA) test, which consists of determining whether there are differences between the means of different populations; thus, in order to know whether there are significant statistical differences in the degree of creativity and levels of physical space (representing a given population), the following procedure was developed.

For the normality test (Table 1), ANOVA was used because it should be when the importance of one or more factors is evaluated when comparing the means 
of the response variable in the different levels of the factors. For the hypothesis test, the selection of the appropriate statistical test is made for its verification.

Table 1: Normality test

\begin{tabular}{|c|c|c|c|}
\hline \multirow{2}{*}{} & \multicolumn{3}{|c|}{ Shapiro-Wilk } \\
\cline { 2 - 4 } & Statistic & Gl & Sig. \\
\hline $\begin{array}{c}\text { Creativity } \\
\text { score }\end{array}$ & .989 & 151 & .272 \\
\hline
\end{tabular}

Consequently, taking into account the results of this process, it can be seen that the $p$-value is greater than the level of significance; therefore, the data come from a normal distribution; then, the ANOVA test will be used.

Once the selection of the corresponding statistical test was made, the general results of the variables development of creativity and physical space were processed; then, assuming an alpha level equal to (0.05), the results of Table 2 are obtained.

Table 2: ANOVA test

\begin{tabular}{|c|c|c|c|c|c|}
\hline Creativity score & sum of squares & gl & Root mean square & f & Sig. \\
\hline Between groups & 7177.420 & 2 & 3588.710 & 1.913 & .151 \\
\hline Inside groups & 277695.984 & 148 & 1876.324 & & \\
\hline Total & 284873.404 & 150 & & & \\
\hline
\end{tabular}

According to the table, the p-value or level of bilateral significance is equal to 0.045 , a value less than the alpha level (which is equal to 0.05); following the established criteria it can be concluded that it is admitted that the probability of relationship between the variables is greater than $95 \%$.

\section{Discussion}

In this study, the use of physical space in the 5-years-old classrooms of the public educational institutions selected was described; and the positive and negative aspects of each classroom were highlighted. One of the problems in the physical space is the infrastructure; in the case of South Arequipa, the classrooms are not large enough for the number of children. This appreciation is corroborated by Vintimilla Padilla and Muñoz Castro (2018), who concluded that, of the ten centres evaluated, $90 \%$ of them do not meet all of the Quality Standards, and only one Children's Centre located in the urban area meets all of the standards evaluated, which represents $10 \%$.

It was also proven that the development of creativity of children in the 5-yearsold classrooms of the public educational institutions of Caylloma is greater than the development of creativity of children in the 5-years-old classrooms of the public educational institutions of South Arequipa. 
The development of creativity of the children of the classroom of 5 years-old of the four public schools of South Arequipa and the four public schools of Caylloma was evaluated. The results were given to the IIEE so that they can be aware of the level of development of the creativity of their students. It is considered the number of children who still have a low development of creativity. This disagrees with the research of Romo, Sánchez and Alfonso (2017), who concludes that overall creativity describes a fundamental upward trend, as well as evaluative skills. It is important to note that we managed to identify greater creativity traits in the classrooms of children who freely use their drawings, without restrictions.

\section{Conclusions}

The appropriate use of physical space is essential to develop creativity in children in cycle II of regular basic education in Peru; due to this it is important to train teachers so that they know the importance of physical space and can correctly organize their classrooms and thus develop children's creativity.

For this reason, it is suggested that talks should be given on the use of physical space, the organization of furniture and materials, which will emphasize the benefits of having furniture that is easily accessible to children and the importance of avoiding an excess of furniture in the classroom. It is convenient to establish a dialogue between teachers, parents and Local Educational Management Units specialists on the importance of the correct implementation of materials in the sectors so that children can develop their creativity through free play. Likewise, a workshop should be held in which teachers learn to conveniently accommodate the furniture and materials in the physical space and complement by commenting on the importance of the development of creativity in the students of the initial level.

\section{References}

Alonso-Sanz, A. (2016). Factores estéticos determinantes de la calidad y el confort en el aula infantile [Aesthetic factors determining quality and comfort in the children's classroom]. Revista Electrónica Interuniversitaria de Formación del Profesorado, 19(3), 53-65. https://doi.org/10.6018/reifop.19.3.267241.

Astorga, B. (2016). Creativity in the classroom. Santiago de Chile, Chile: JUNJI. Ediciones de la JUNJI.

Britton, L. (1992). Montessori Play and Learn: a parents' guide to purposeful play from two to six. Three Rivers Press, Nueva York, NY, USA.

Cayuela, M. A. (2018, October 14). El auténtico motor del aprendizaje en la escuela es la creatividad [The real engine of learning at school is creativity]. Diario La Verdad. Retrieved from https://www.laverdad.es/murcia/autentico-motoraprendizaje-20181014002530-ntvo.html.

Cernades Ramírez, I. (2008). Desarrollo de la creatividad en educación infantil. Perspectiva constructivista [Development of creativity in early childhood education. Constructivist perspective]. Revista Creatividad y Sociedad, 12, 7-20.

García-Chato, G. (2014). Ambiente de aprendizaje: su significado en preescolar [Learning environment: its meaning in preschool]. Revista de Educación y Desarrollo, 29, 6372.

Gardner, H. (1983). Frames of mind. New York, NY, USA: Basic Books. 
Guilford, J. P. (1950). Creativity. American Psychologist, 5, 444-454.

Hinostroza, A. (2007). Creative expressions. San Marcos, Lima, Peru.

Iglesias Forneiro, M. L. (2008). Observación y Evaluación del Ambiente de Aprendizaje en Educación Infantil: Dimensiones y Variables a Considerar [Observation and Evaluation of the Learning Environment in Early Childhood Education: Dimensions and Variables to Consider]. Revista Iberoamericana de Educación, 49, 49-70. https://doi.org/10.35362/rie470704

Kim, K. H. (2006). Can We Trust Creativity Tests? A Review of the Torrance Tests of Creative Thinking (TTCT). Creativity Research Journal, 18(1), 3-14. https://doi.org/10.1207/s15326934crj1801_2

Klimenko, O. (2008). La creatividad como un desafío para la educación del siglo XXI [Creativity as a challenge for 21st century education]. Educación y educadores, 11(1), 191-210.

López-Megías, L. \& Fernández-Castillo, A. (2018). Creatividad en la infancia temprana. Análisis cualitativo en un contexto educativo [Creativity in early childhood. Qualitative analysis in an educational context]. ReiDoCrea, 7, 43-54.

Medina Sánchez, N., Velázquez Tejeda, M. E., Alhuay-Quispe, J. \& Aguirre Chávez, F. (2017). Creativity in Preschoolers, a Challenge of the Contemporary Education. REICE. Revista Iberoamericana sobre Calidad, Eficacia y Cambio en Educación, 15(2), 153-181. http://dx.doi.org/10.15366/reice2017.15.2

Rutas del aprendizaje. Qué y cómo aprenden nuestros niños y niñas? [Learning routes. What and how do our children learn?].[Brochure]. (2015). Lima, Perú: Ministerio de Educación.

Entorno educativo de calidad en educaciòn inicial: Guía para docentes del Ciclo II [Quality educational environment in initial education: Guide for Cycle II teachers] [Brochure]. (2016). Lima, Perú: Dirección General de Educación Básica Regular, Dirección de Educación Inicial, Ministerio de Educación.

¿Cómo se relaciona la infraestructura de la escuela con los aprendizajes de los estudiantes? (Zoomeducativo $\mathrm{N}^{\circ} 3$ ) [How is the school infrastructure related to student learning?] [Brochure]. (2017). Lima, Perú: Oficina de Medición de la Calidad de los Aprendizajes, Ministerio de Educación.

Pauta de observación de la gestión del espacio y los materiales del aula [Observation guideline for classroom space and materials management] [Brochure]. (2017). Lima, Perú: Ministerio de Educación.

Pagliero Caro, M.J. \& Piderit Moreno, M.B. (2017). Evaluación y percepción de la iluminación natural en aulas de preescolar, Región de los Lagos, Chile [Evaluation and perception of natural lighting in preschool classrooms, Los Lagos Region, Chile]. Revista científica de Arquitectura y Urbanismo, 38(3), 41-59.

Polanco, A. (2004). El ambiente en un aula del ciclo de transición [The atmosphere in a classroom of the transition cycle]. Actualidades Investigativas en Educación, 4(1), 015. http://dx.doi.org/10.15517/AIE.V4I1.9049

Torrance, E. P. (1962). Guiding creative talent. Nueva Jersey, USA: Prentice Hall.

Torrance, E. P. (1972). Predictive Validity of the Torrance Tests of Creative Thinking. The Journal of Creative Behavior, 6(4), 236-262. https://doi.org/10.1002/j.21626057.1972.tb00936.x.

Romo, M., Sanches-Ruiz, M.J. \& Alfonso-Benlliure, V. (2017). Creativity and personality across domains: A critical review. The UB Journal of psychology, 47(2), 57-70. http://dx.doi.org/10.1016/j.anpsic.2017.04.003

Ruiz Gutiérrez, S. \& Rebollo Aranda, M.S. (2015). El aula de Educación Infantil: el aula creative [The Pre-Primary classroom: a creative classroom]. Revista de la Facultad 
$\begin{array}{lllll}\text { de Educación } & \text { de } & \text { Albacete, } & \text { 30(2), } & \text { 73-74. }\end{array}$ https://doi.org/10.18239/ensayos.v30i2.647

Vintimilla Padilla, E. T. \& Muñoz Castro, E. N. (2018). Estándares de calidad de los Centros Infantiles del Buen Vivir del cantón Cuenca 2017 [Quality standards of the Buen Vivir Children's Centres of the canton Cuenca 2017] (Bachelor's Thesis). Universidad de Cuenca, Cuenca, Ecuador. 